\title{
Pengembangan Bioaktivator Berbasis Mikroba Berbagai Jenis Mol Untuk Pengomposan Limbah Tandan Kosong Kelapa Sawit Dalam Memperbaiki Sifat Tanah Bekas Tambang Batubara
}

\section{Microbial Bio-Activator Development Different Types of Moles For Composting Wastes Of Oil Palm Bunches In Improving Typical Soil Forms of Coal Mine}

\author{
Muhamad Hidayanto ${ }^{1}$, Nurul Puspita Palupi ${ }^{2}$, Roro Kesumaningwati ${ }^{2}$, dan Zainudin ${ }^{3}$ \\ ${ }^{1}$ Peneliti Balai Pengkajian Teknologi Pertanian Kalimantan Timur \\ ${ }^{2}$ Tenaga Pendidikan Program Studi Agroteknologi, Fakultas Pertanian, Universitas Mulawarman Jl. Pasir Balengkong \\ Kota Samarinda, Kalimantan Timur 75117 \\ ${ }^{3}$ Tenaga Pendidik Program Studi Agroteknologi, Fakultas Pertanian, Universitas Widya Gama Mahakam \\ Jl. KH. Wahid Hasyim, Sempaja, Samarinda, Kalimantan Timur, Indonesia \\ email : m.hidayanto@litbang.pertanian.go.id,nurulpuspita2908@gmail.com,rorokesuma99@gmail.com, \\ zainudin@uwgm.ac.id
}

Diterima : 17 Mei 2017 Disetujui : 2 Juni 2017

\begin{abstract}
Improvement of agricultural development requires improvement of supporting factors of agricultural cultivation, especially the improvement of soil conditions using organic fertilizers. Organic fertilizers should go through the composting process to provide nutrients faster for plants. The composting process requires bioactivators to accelerate the decomposition of organic matter. Selection of bioactivators used in the composting process should be more careful considering each organic material has a different $C / N$ ratio. Composting of organic materials with low $C / N$ ratios generally does not have many obstacles, but the composting of organic materials with high $C / N$ as in oil palm empty bunches requires a bioactivator capable of decomposing high levels of lignin in oil palm empty bunches. Development of bioactivators is a step that must be done in order to find a bioactivator that can accelerate the decomposition process, especially for organic materials with high $C / N$ as in oil palm empty bunches. The research stages include: Identification, isolation and selection of potential microbials from maschy mole mol, gamal leaf mole, and fish waste mole, Analysis of mole chemistry, Mole application test to waste of empty palm oil bunches. The experimental method used in the fermentation stage of waste bunch of empty palm oil with 2 factors. The first factor is the MOL type, the second factor is the MOL concentration. The first factor consists of 3 treatments, the second factor consists of 4 treatments so that there are 12 treatments. The experiment was performed with 4 replications. First Factor; $p 1=$ mol snail mas $(\mathrm{km}), \mathrm{p} 2=$ mol gamal leaf $(\mathrm{dg}), \mathrm{p} 3=$ mol of fish waste (li). The second factor was $\mathrm{kl}=100 \mathrm{ml}$ of bioactivator / liter water solution, $\mathrm{k} 2=150 \mathrm{ml}$ of bioactivator $/$ liter water solution, $k 3=200 \mathrm{ml}$ of bioactivator / liter water solution, $k 4=250 \mathrm{ml}$ of bioactivator / liter water solution.The results showed 1) the microorganisms identified in Koong Mas mole were Black Niger Aspergillus, Penicillium, and Trichoderma. In MOL Leaves of Gamal are Bacillus Biru, Bacillus Merah, Pythium, and Trichoderma. In MOL Fish Waste is Thricoderma. 2) Compost of empty palm oil bunches has not been decomposed perfectly because it has $C / N>25$, but has provided nutrient elements of $\mathrm{pH}$, total $\mathrm{N}$, and $\mathrm{K}$ total according to SNI 19-7030-2004 standard. The high C / N ratio is probably due to environmental factors ie high temperatures at the composting site and the lack of moisture in the compost thus inhibiting the decomposition process.
\end{abstract}

Key words: Local microorganisms, organic farming, and bioactivators

\section{PENDAHULUAN}

Sektor pertanian merupakan sektor yang mempunyai peranan strategis dalam pembangunan perekonomian nasional. Pembangunan pertanian di masa kini tidak hanya dihadapkan untuk memecahkan masalah yang ada, namun juga dihadapkan pula pada tantangan untuk menghadapi perubahan tatanan politik di Indonesia yang mengarah pada era demokratisasi yakni tuntutan otonomi daerah dan pemberdayaan petani. Pembangunan pertanian di Indonesia tidak saja dituntut untuk menghasilkan produk-produk pertanian yang berdaya saing tinggi namun juga mampu mengembangkan pertumbuhan daerah serta pemberdayaan masyarakat. Tantangan tersebut menjadi sebuah kerja keras bagi kita semua apabila menginginkan pertanian kita dapat menjadi pendorong peningkatan kesejahteraan masyarakat dan dapat menjadi motor penggerak pembangunan bangsa.

Penggunaan pupuk cair dengan memanfaatkan jenis MOL menjadi alternatif penunjang kebutuhan unsur hara dalam tanah. Larutan MOL mengandung unsur hara makro, mikro, dan mengandung mikroorganisme yang berpotensi sebagai perombak bahan organik, perangsang pertumbuhan, dan agen pengendali hama dan penyakit tanaman sehingga baik 
digunakan sebagai dekomposer, pupuk hayati,

MOL yang digunakan dalam penelitian ini antara lain mol keong mas, daun gamal, dan limbah ikan. MOL mengandung berbagai macam mikroorganisme yang bermanfaat dalam proses pembuatan kompos, tetapi belum dilakukan identifikasi dan seleksi mikroba apa saja yang terdapat dalam ketiga jenis mol ini, serta belum diketahui ada tidaknya mikroba yang memiliki sifat lignosellulotik pada ketiga jenis mol tersebut. Keong mas dengan nama latin Pomacea Canaliculata Lammarck ini termasuk hewan golongan moluska karena bertubuh lunak. Bagi petani, keong mas merupakan hama yang berbahaya karena menyerang tanaman padi. Keong mas selain dikenal sebagai hama perusak padi, ternyata keong mas memiliki kandungan gizi seperti asam omega 3, 6 dan 9. Dari hasil uji proksimat, kandungan protein pada keong mas berkisar antara 16 hingga 50 persen, sehingga sangat potensial digunakan sebagai media pembiakan alternatif bakteri. Tingginya kandungan protein tersebut dapat dipertimbangkan sebagai bahan baku pembuatan pepton yang merupakan sumber nitrogen utama dalam media mikrobiologi untuk pertumbuhan bakteri, sehingga keong mas dapat dijadikan sebagai bahan pembuatan MOL, selain itu keong mas juga memiliki kandungan gizi lemak $0,37 \%$, kadar abu $1,74 \%$, serat kasar $0,61 \%$, rendemen $18 \%$, kalsium $29,3 \%$, dan phosphor $0,19 \%$.

Pemanfaatan daun gamal (Gliricidia sepium) sebagai bahan baku pembuatan MOL dalam penelitian ini karena keberadaan tanaman gamal yang melimpah pada lahan bekas tambang tambang batubara, selain itu tanaman gamal merupakan salah satu jenis tanaman leguminosa dengan kandungan unsur hara yang tinggi. Gamal yang berumur satu tahun mengandung 3-6\% N; 0,31 \% P; $0,77 \% \mathrm{~K} ; 15-$ $30 \%$ serat kasar; dan $10 \%$ abu K (Purwanto, 2007). Penelitian Muriani (2011) menyimpulkan bahwa perlakuan konsentrasi $300 \mathrm{~g}$ daun gamal dan fermentasi tiga minggu memberikan kualitas larutan MOL yang terbaik sebagai pupuk cair dan konsentrasi $300 \mathrm{~g}$ daun gamal dengan lama fermentasi dua minggu memberikan kualitas yang terbaik sebagai aktivator. Limbah ikan juga melimpah keberadaannya di Kalimantan Timur. Limbah ikan ini sangat jarang dimanfaatkan dan memiliki kandung protein tinggi yang baik bagi perkembangan mikroorganisme pengurai bahan organik. Pemanfaatan kompos tandan kosong

\section{BAHAN DAN METODE}

dan pestisida organik (Purwasasmita, 2009). kelapa sawit masih jarang terutama di kalangan petani di Kaltim. Padahal teknologi produksi kompos dari tandan kosong sawit (TKS) merupakan satu teknologi pengolahan limbah yang sekaligus dapat mengatasi masalah limbah padat dan limbah cair di pabrik pengolahan kelapa awit hingga pabrik mempu menerapkan konsep zero waste yang berarti tidak ada lagi limbah padat dan cair yang terbuang.

Teknologi kompos dengan menggunakan starter mikroorganisme lokal (MOL) diyakini dapat digunakan untuk menghasilkan pupuk organik berkualitas mengingat pada prosesnya melibatkan bakteri pengurai bahan organik. Teknologi kompos asal limbah tandan kosong kelapa sawit sangat memungkinkan untuk dikembangkan, baik di tingkat petani maupun perusahan swasta kelapa sawit.

Provinsi Kalimantan Timur merupakan basis penambangan batubara di wilayah Indonesia Timur. Sekitar 9800 ha lahan telah dibuka sebagai areal penambangan, sehingga sejumlah itu pula kemungkinan besar menjadi lahan terbuka tak termanfaatkan.

Tanah bekas penambangan batubara memerlukan penanganan khusus terutama untuk memperbaiki sifat fisika, kimia dan biologi tanah. Salah satu penanganannya adalah dengan penerapan pertanian organik yakni mengembalikan produk limbah pertanian ke lahan pertanian sehingga unsur-unsur hara yang terangkut melalui sisa panen pertanian sebagian dapat dikembalikan secara alami. Pertanian organik merupakan teknik budidaya pertanian dengan menggunakan bahan-bahan dari alam dan tidak menggunakan bahan kimia sintetis. Pertanian organik bertujuan untuk menyediakan produk pertanian, utamanya adalah bahan pangan yang aman bagi kesehatan manusia dan tidak mengakibatkan kerusakan lingkungan. Budidaya pertanian secara organik juga dimaksudkan untuk meningkatkan taraf hidup petani karena produk pertanian organik memiliki nilai jual yang lebih tinggi sehingga akan meningkatkan pendapatan petani. Pertanian organik bila diusahakan secara intensif dapat mengembalikan kesuburan tanah terutama tanah yang telah mengalami degradasi seperti tanah pasca tambang batubara walaupun membutuhkan waktu yang cukup lama untuk mencapai tingkat kesuburan tanah seperti pada saat sebelum penggunaan pupuk dan pestisida anorganik yang berlebihan (Sutanto, 2002).

Tahapan penelitian yang dilakukan (Tahun 2015) meliputi : 
1.Identifikasi, isolasi dan seleksi mikroba potensial dari mol keong mas, mol daun gamal, dan mol limbah ikan.

2. Analisis kandungan kimia mol.

3.Uji aplikasi mol ke limbah tandan kosong kelapa sawit .

4.Pemilihan kompos limbah tandan kosong kelapa sawit dengan kualitas terbaik

Metode eksperimental digunakan pada tahap fermentasi limbah tandan kosong kelapa sawit dengan 2 faktor. Faktor pertama adalah jenis

\section{HASIL DAN PEMBAHASAN}

Hasil Analisis Kimia Mol Keong Mas, Mol Daun Gamal, Dan Mol Limbah Ikan

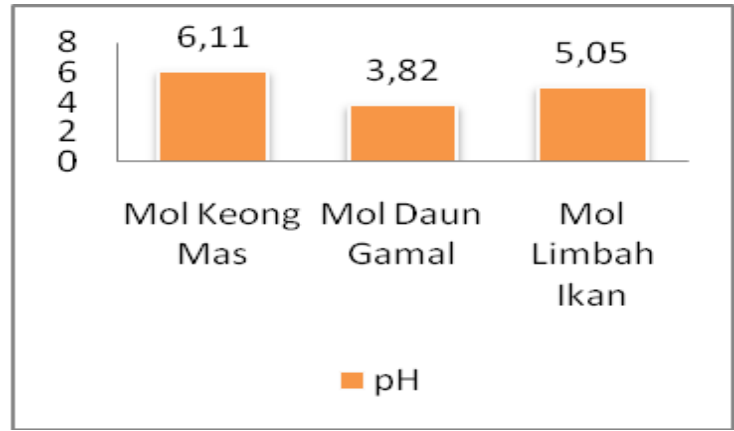

Gambar 1. Hasil Analisis pH Mol Keong Mas, Mol Mol Daun Gamal dan Mol Limbah Ikan

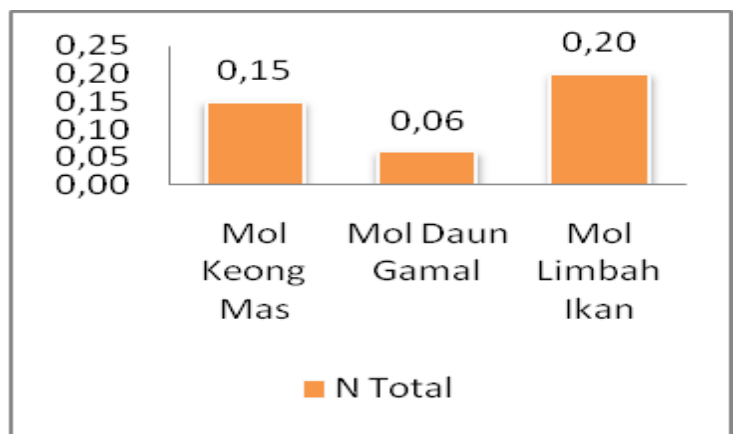

Gambar 3. Hasil Analisis N Total Mol Keong Mas, Mol Daun Gamal dan Mol Limbah Ikan

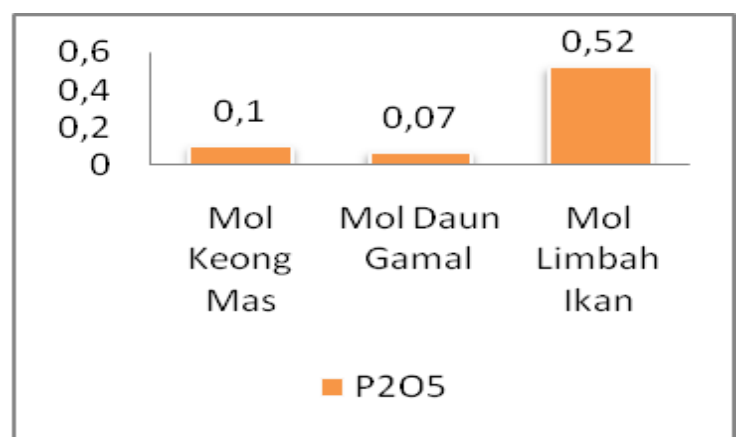

Gambar 5. Hasil Analisis P2O5 Mol Keong Mas, Mol Daun Gamal dan Mol Limbah Ikan
MOL, faktor kedua adalah konsentrasi MOL. Faktor pertama terdiri atas 3 perlakuan, faktor kedua terdiri atas 4 perlakuan sehingga ada 12 perlakuan.

Percobaan dilakukan dengan 4 ulangan. Faktor pertama $; \mathrm{p} 1=$ mol keong mas $(\mathrm{km}), \mathrm{p} 2=$ mol daun gamal (dg), p3 = mol limbah ikan (li) dan faktor kedua ; $\mathrm{k} 1=100 \mathrm{ml}$ larutan bioaktivator /liter air, k2 $=150 \mathrm{ml}$ larutan bioaktivator /liter air, k3 = $200 \mathrm{ml}$ larutan bioaktivator /liter air, $\mathrm{k} 4=250 \mathrm{ml}$ larutan bioaktivator /liter air.

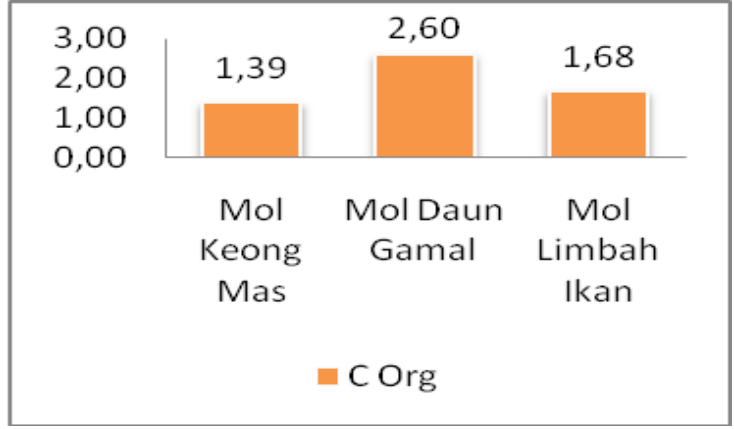

Gambar 2. Hasil Analisis C Org (\%) Mol Keong Mas, Mol Daun Gamal dan Mol Limbah Ikan Mas,

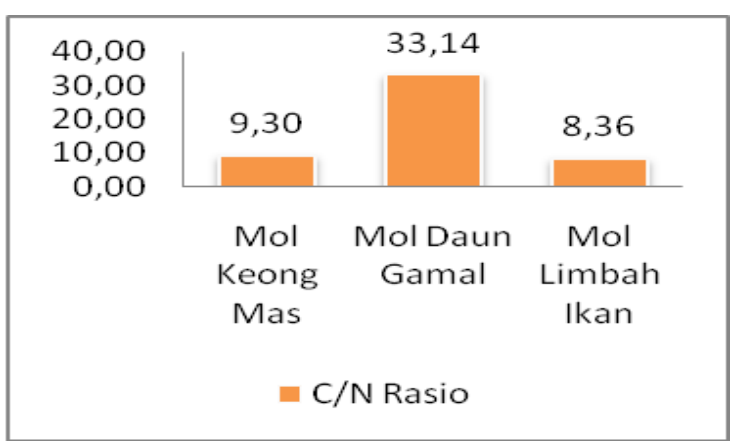

Gambar 4. Hasil Analisis C/N Rasio Mol Keong Mas, Mol Daun Gamal dan Mol Limbah Ikan Mas,

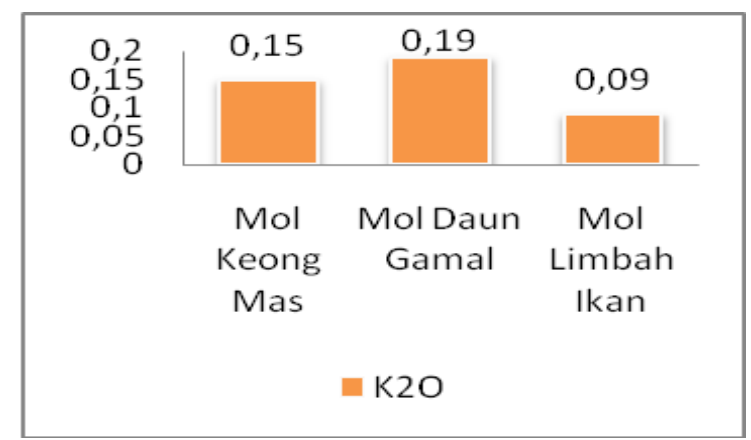

Gambar 6. Hasil Analisis K2O Mol Keong Mas, Mol Daun Gamal dan Mol Limbah Ikan Mas, 


\section{Hasil Analisis Kompos Tandan Kosong Kelapa Sawit}

Tabel 1. Hasil analisis kimia kompos tandan kosong kelapa sawit dengan menggunakan mol keong mas, mol daun gamal, dan mol limbah ikan dengan dosis yang berbeda

\begin{tabular}{|c|c|c|c|c|c|c|c|c|}
\hline KOMPOS TKKS & pH & $\underset{(\%)}{\text { Kadar Air }}$ & $\begin{array}{c}\text { C org } \\
(\%)\end{array}$ & $\begin{array}{c}\mathbf{N} \text { total } \\
(\%)\end{array}$ & $\begin{array}{c}\mathbf{P}_{2} \mathbf{O}_{5} \\
(\%)\end{array}$ & $\begin{array}{l}\mathrm{K}_{2} \mathrm{O} \\
(\%)\end{array}$ & $\begin{array}{c}\text { KTK } \\
\left(\mathrm{cmol}^{+} \mathbf{k g}^{-1}\right)\end{array}$ & $\mathbf{C} / \mathbf{N}$ \\
\hline Kontrol & 6,48 & 6,94 & 44,76 & 0,40 & 0,04 & 1,00 & 3,30 & 112 \\
\hline Kompos km(konsentrasi $0,1 \%$ ) & 7,49 & & 36,46 & 0,39 & 0,04 & 1,34 & 3,89 & 94 \\
\hline Kompos $\mathrm{km}$ (konsentrasi $0,15 \%$ ) & 7,39 & 7,86 & 35,67 & 0,43 & 0,04 & 1,35 & 2,68 & 82 \\
\hline Kompos km (konsentrasi $0,2 \%$ ) & 8,17 & 9,00 & 35,58 & 0,38 & 0,05 & 1,63 & 2,64 & 94 \\
\hline Kompos km (konsentrasi $0,25 \%$ ) & 8,30 & 8,23 & 35,70 & 0,33 & 0,04 & 1,52 & 2,04 & 108 \\
\hline Kompos dg (konsentrasi $0,1 \%$ ) & 8,36 & 8,53 & 35,65 & 0,27 & 0,05 & 1,57 & 4,54 & 131 \\
\hline Kompos dg (konsentrasi $0,15 \%)$ & 8,09 & 7,68 & 36,12 & 0,38 & 0,05 & 1,59 & 3,64 & 96 \\
\hline Kompos dg & 8,09 & 7,96 & 36,19 & 0,3 & 0,04 & 1,29 & 2,87 & 106 \\
\hline Kompos dg (konsentrasi $0,25 \%$ ) & 8,07 & 8,63 & 35,52 & 0,55 & 0,05 & 1,69 & 3,41 & 65 \\
\hline Kompos li (konsentrasi $0,1 \%$ ) & 6,98 & 7,17 & 35,69 & 0,34 & 0,05 & 1,53 & 3,59 & 106 \\
\hline Kompos li (konsentrasi 0,15\%) & 7,97 & 8,42 & 35,53 & 0,40 & 0,07 & 1,77 & 2,86 & 90 \\
\hline Kompos li (konsentrasi 0,2\%) & 7,49 & 8,38 & 35,99 & 0,41 & 0,09 & 1,34 & 3,20 & 88 \\
\hline Kompos li (konsentrasi $0,25 \%$ ) & 8,53 & 11,13 & 34,68 & 0,45 & 0,13 & 1,82 & 4,24 & 77 \\
\hline
\end{tabular}

Berdasarkan tabel 1 diatas diperoleh hasil bahwa Tandan kosong kelapa sawit memiliki kandungan lignin yang tinggi sehingga memerlukan waktu yang lama untuk mendekomposisinya. Rasio $\mathrm{C} / \mathrm{N}$ yang masih cukup tinggi merupakan indikasi bahwa unsur hara dalam kompos tersebut belum terdapat dalam bentuk tersedia dalam jumlah yang cukup untuk meningkatkan produksi tanaman. Hasil penelitian Baon et al dalam Rubiyo dkk. (2003) melaporkan bahwa bahan organik yang dapat larut dengan tanah adalah yang memiliki rasio $\mathrm{C} / \mathrm{N}$ tidak lebih dari 15. Selain itu, masa dekomposisi kompos cukup pendek sehingga nitrogen dan unsur-unsur hara yang lain belum mengalami mineralisasi dengan sempurna.

\section{Hasil Analisis Mikroorganisme dalam MOL Keong Mas, Mol Daun Gamal, dan MOL Limbah Ikan}

Tabel 2. Identifikasi mikroorganisme dalam MOL

\begin{tabular}{cllll}
\hline \multicolumn{1}{c}{ MOL } & \multicolumn{1}{c}{ Parameter } & \multicolumn{1}{c}{ Satuan } & \multicolumn{1}{c}{ Jumlah Mikroba } & Metode \\
\hline Keong Mas & Bakteri Lignolittik & $\mathrm{Cfu} / \mathrm{ml}$ & $2,81 \times 10^{6}$ & Pour Plate \\
& Jamur Lignolitik & Propagul $/ \mathrm{mL}$ & $4,45 \times 10^{3}$ & Pour Plate \\
& Bakteri Selulotik & $\mathrm{Cfu} / \mathrm{ml}$ & $7,9 \times 10^{4}$ & Pour Plate \\
Daun Gamal & Bakteri Lignolitik & $\mathrm{Cfu} / \mathrm{ml}$ & $6,15 \times 10^{3}$ & Pour Plate \\
& Bakteri Selulotik & $\mathrm{Cfu} / \mathrm{ml}$ & $4,6 \times 10^{4}$ & Pour Plate \\
Limbah Ikan & Bakteri Lignolitik & $\mathrm{Cfu} / \mathrm{ml}$ & $1,6 \times 10^{4}$ & Pour Plate \\
& Bakteri Selulotik & $\mathrm{Cfu} / \mathrm{ml}$ & $1,45 \times 10^{3}$ & Pour Plate \\
\hline
\end{tabular}

Berdasarkan hasil uji identifikasi dan konsentrasi mikroba MOL diatas menunjukkan bahwa masing-masing MOL memiliki konsentrasi sel hidup yang meliputi total bakteri lignolitik, selulotik dan fungi selulotik yang beragam. Mikroorganisme merombak bahan organik, melepas hara anorganik yang dibutuhkan tanaman. Jika mikroorganisme tidak ada maka bahan organik akan berakumulasi, unsur hara tidak tersedia. Mikroorganisme dapat menghasilkan asam-asam organik seperti asam

Mikroorganisme merombak bahan organik, melepas hara anorganik yang dibutuhkan glukonat (bakteri), asam sitrat, asam oksalat (fungi) dapat melarutkan mineral, namun fosfat besi, fosfat aluminium resisten terhadap asamasam tersebut, tetapi dapat larut oleh as.hidrogen sulfida yang juga dihasilkan oleh mikrooranisme. Sebagian besar pengurai silikat dan fosfat ditemukan di dalam tanah yang cukup bahan organik sebagai substrat mikroorganisme. Kobus (1962), mengestimasi bahwa $8-95 \%$ m.o yang diteliti dari berbagai contoh tanah dapat menguraikan kalsiumdifosfat.

tanaman, sehingga jika mikroorganisme tidak ada maka bahan organik akan berakumulasi, 
unsur hara tidak tersedia. Mikroorganisme dapat menghasilkan asam-asam organik seperti asam glukonat (bakteri), asam sitrat, asam oksalat (fungi) dapat melarutkan mineral, namun fosfat besi, fosfat aluminium resisten terhadap asamasam tersebut, tetapi dapat larut oleh asam hidrogen sulfida yang juga dihasilkan oleh mikrooranisme. Sebagian besar pengurai silikat dan fosfat ditemukan di dalam tanah yang cukup bahan organik sebagai substrat mikroorganisme.

Jamur yang sudah teridentifikasi pada semua MOL di atas adalah jamur Penicillium sp, Aspergillus sp. dan Trichoderma sp. Jamurjamur ini merupakan dekomposer. Dekomposer atau jamur saprofit yaitu jamur yang mampu mengubah bahan organik menjadi biomas jamur, karbondioksida, dan asam-asam organik. Jamur ini mempunyai peranan penting dalam dekomposisi bahan-bahan organik yang keras seperti kayu. Mengkonsumsi unsur hara dalam bahan organik, jamur memainkan peranan penting dalam immobilisasi dan penahan unsur hara dalam tanah. Asam-asam organik yang diproduksi jamur membantu dalam degradasi bahan-bahan organik yang sangat sulit untuk dihancurkan. Keberadaan jamur-jamur ini mampu menyediakan unsur-unsur hara yang dapat diserap tanaman. Metabolit mikroba yang bersifat antagonis bagi mikroba lainnya seperti antibiotik dapat pula dimanfaatkan untuk menekan mikroba patogen tular tanah disekitar perakaran tanaman. Dalam memenuhi kebutuhan hidupnya mikroba tanah melakukan immobilisasi berbagai unsur hara sehingga dapat mengurangi hilangnya unsur hara melalui pencucian. Unsur hara yang diimobilisasi diubah sebagai massa sel mikroba dan akan kembali lagi tersedia untuk tanaman setelah terjadi mineralisasi yaitu apabila mikroba mati.

Berdasarkan hasil penelitian, Mikroorganisme lokal diketahui mengandung jamur Trichoderma sp. Trichoderma ini banyak spesiesnya yang sudah diketahui bersifat antagonis terhadap jamur patogen. T. harzianum efektif mengendalikan sklerotia dari jamur Sclerotium rolfsii yang banyak menyebabkan penyakit rebah kecambah pada tanaman inang yang diserangnya. $T$. polysporum efektif terhadap jamur Fomes annosus. T. viridae dapat memparasit jamur Armillaria mellea. Keunggulan jamur Trichoderma sebagai agensia pengendali hayati dibandingkan dengan jenis fungisida kimia sintetik adalah selain mampu mengendalikan jamur patogen dalam tanah, ternyata juga dapat mendorong adanya fase revitalisasi tanaman. Revitalisasi ini terjadi karena adanya mekanisme interaksi antara tanaman dan agensia aktif dalam memacu hormon pertumbuhan tanaman (Suwahyono dan Wahyudi, 2004).

\section{KESIMPULAN}

1. Mikroorganisme yang teridentifikasi pada mol Keong Mas adalah Aspergillus Niger Hitam, Penicillium, dan Trichoderma. Pada MOL Daun Gamal adalah Bacillus Biru, Bacillus Merah, Pythium, dan Trichoderma. Pada MOL Limbah Ikan adalah Thricoderma.

2. Kompos tandan kosong kelapa sawit belum terdekomposisi sempurna karena memiliki $\mathrm{C} / \mathrm{N}>25$, tetapi sudah menyediakan unsur hara $\mathrm{pH}, \mathrm{N}$ total, dan $\mathrm{K}$ total sesuai standar SNI 19-7030-2004. Masih tingginya rasio $\mathrm{C} / \mathrm{N}$ kemungkinan disebabkan karena faktor lingkungan yaitu suhu yang tinggi pada tempat pembuatan kompos serta kurangnya kelembaban kompos sehingga menghambat proses dekomposisi.

\section{DAFTAR PUSTAKA}

Balai Penelitian Tanah. 2005. Petunjuk Teknis Analisis Kimia Tanah, Tanaman, Air, dan Pupuk. Badan Penelitian dan Pengembangan Pertanian. Departeman Pertanian. Bogor.

Handayani, Ahmad Y, Ari S. Uji Kualitas Pupuk Organik Cair Dari Berbagai Macam Mikroorganisme Lokal (Mol). El-Vivo Vol.3, No.1, Hal 54 - 60, April 2015 Issn: 2339-1901.

Jusuf, L, Mulyati A.M., Dan A.H. Sanaba. Pengaruh Dosis Pupuk Organik Padat Daun Gamal Terhadap Tanaman Sawi. Jurnal Agrisistem, Desember 2007, Vol. 3 No. 2 Issn 1858-4330.

Kastalani. 2010. Pengaruh Tingkat Konsentrasi dan Lamanya Inkubasi EM4 Terhadap Kualitas kimia Pupuk Bokashi. Media SainS, Volume 2 Nomor 2, Oktober 2010. ISSN 2085-3548. Hal 146-152.

Kesumaningwati, R., Dhonanto, D dan Palupi, N. P. 2013. Aplikasi tandan kosong kelapa sawit dan mikroorganisme lokal (MOL) keong emas pada tanah bekas tambang batubara. Laporan Hibah Bersaing DIKTI. Samarinda.

Kusuma, M. 2012. Pengaruh Beberapa Jenis Pupuk Kandang Terhadap Kualitas Bokashi. Jurnal Ilmu Hewani Tropika Vol 
1 No. 2 Desember 2012. ISSN : 23017783. Hal 41-46.

Nurchayati, Y, Titis Y. Pertumbuhan Tongkol Jagung Baby Corn (Zea Mays L.) Varietas Pioneer-11 Setelah Pemberian Kascing. Jurnal Sains \& Matematika (JSM) ISSN 0854-0675. Volume14, Nomor 4, Oktober 2006.

Parnata, Ayub. S. 2004. Pupuk Organik Cair (Aplikasi dan Manfaatnya) Agromedia Pustaka. Jakarta.

PPKS, 2008. Jurnal Penelitian Kelapa Sawit. Vol 13 No. 2.

Subandriyo, Didi D.A, Hadiyanto. Optimasi Pengomposan Sampah Organik Rumah
Tangga Menggunakan Kombinasi Aktivator Em4 Dan Mol Terhadap Rasio C/N. Jurnal Ilmu Lingkungan. Volume 10 Issue 2: $70-75$ (2012) Issn 1829-8907.

Yadnya Seni, I. A., I Wayan D. A., Ni W. S. Analisis Kualitas Larutan Mol (Mikoorganisme Lokal) Berbasis Daun Gamal (Gliricidia Sepium). E-Jurnal Agroekoteknologi Tropika ISSN: 23016515 Vol. 2, No. 2, April 2013.

Yuwono, M. 2008. Dekomposisi dan Mineralisasi Beberapa Macam Bahan Organik. Jurnal Agronomi Vol. 12 No. 1, Januari - Juni 2008. ISSN 1410-1939. Hal $1-8$. 